\title{
Fasies dan Lingkungan Pengendapan Formasi Kanikeh, Cekungan Bula, Maluku
}

\author{
Akhmad Khahlil Gibran $^{1 *}$, Aries Kusworo ${ }^{2}$ \\ ${ }^{1}$ Jurusan Teknik Geologi, Fakultas Teknik, Universitas Jenderal Soedirman \\ ${ }^{2}$ Pusat Survei Geologi, Badan Geologi, Kementerian Energi dan Sumberdaya Mineral
}

\begin{abstract}
ABSTRAK Batuan silisiklastik berumur Trias yaitu Formasi Kanikeh, tersebar di Pulau Seram hingga Pulau Kesui dan Teor dari Maluku hingga Maluku Tenggara. Formasi Kanikeh telah lama dikenal memiliki karakteristik batuan induk yang baik. Pemahaman tentang Formasi Kanikeh masih minim, interpretasi lingkungan pengendapan dan korelasi stratigrafi masih ada perbedaan. Tujuan penelitian ini adalah mendapatkan hasil interpretasi lingkungan pengendapan berdasarkan data terbaru. Metode yang digunakan dalam penelitian ini adalah pengukuran penampang stratigrafi pada empat lintasan pengamatan di daerah Seram Bagian Timur dengan menggunakan pendekatan analisis litofasies dan asosiasi fasies. Hasil dari penelitian ini menunjukkan adanya 9 litofasies, yaitu: Litofasies Batupasir Konglomeratan (Sg); Litofasies Batupasir Lapisan Silangsiur Mangkok (Sp); Litofasies Batupasir Bioturbasi (Sb); Litofasies Batupasir Karbonan (Sc); Litofasies Batupasir Bergelombang (Sw); Litofasies Batupasir Flasser (Sf); Litofasies Batupasir Laminasi Sejajar (Sh); Litofasies Batulumpur Lentikuler (Fl); Litofasies Batulumpur Berlapis (Fsc). Deskripsi litofasies tersebut termasuk ke dalam suatu sistem pengendapan pasang-surut (intertidal) yaitu tidal channel, tidal sand flat, tidal sand-mud mixed flat, dan tidal mudflat. Formasi Kanikeh terendapkan dengan sistem pengendapan batuan silisiklastik yang dipengaruhi oleh arus pasang-surut pada lingkungan pengendapan transisi.
\end{abstract}

Naskah masuk : : 11 Mei 2020

Naskah direvisi : 26 Juni 2020

Naskah diterima : 27 Juni 2020

* Penulis korespondensi.

E-mail: akgibran@unsoed.ac.id
Kata kunci: Formasi Kanikeh, silisiklastik, lingkungan pengendapan, litofasies, asosiasi fasies.

ABSTRACT - Facies and depositional environment of Kanikeh Formation, Bula Basin, Molucca. The Triassic siliciclastic rocks of Kanikeh Formation spread across Seram, Kesui and Teor islands from Molucca to Southeast Molucca. The Kanikeh Formation has been known as an excellent source rock. However, its depositional environment and stratigraphic correlation interpretations are still poorly understood. This study aims to give better understanding of depositional environment. This study describes lithofacies descriptions and facies associations of four stratigraphy measuring sections in Eastern Seram Island. The results show there are 9 lithofacies, including conglomeratic sandstone (Sc); Trough cross-bedded sandstone (Sp); Bioturbated sandstone (Sb); Carboniferous sandstone (Sc); Wavy Sandstone (Sw); Flasser Sandstone (Sf); Parallel-laminated sandstone (Sh); Lenticular mudstone (Fl); and Laminated mudstone (Fsc). The lithofacies description is included in four facies associations in a tidal deposition system (intertidal) that comprises tidal channels, tidal sand flat, tidal sand-mud mixed flat, dan tidal mudflat. Based on our results the Kanikeh Formation was deposited in a siliciclastic deposition system influenced by tidal currents within transition deposition environments.

Keywords: Kanikeh Formation, siliciclastic, depositional environment, lithofacies, facies association.

\section{PENDAHULUAN}

Di Cekungan Bula terdapat dua blok wilayah kerja minyak dan gas bumi yang sedang aktif, yaitu blok Bula dengan play batupasir dan batugamping berumur Kuarter dan blok Oseil dengan play 
batugamping berumur Jura. Berdasarkan analisis biomarker, minyak bumi dari lapangan Bula dan lapangan Oseil berasal dari sumber yang sama (Wahyudiono dkk., 2018a). Formasi Kanikeh telah lama dikenal memiliki karakteristik batuan induk yang baik (Kemp dan Mogg, 1992; Surjono dan Wijayanti, 2012; Adlan dkk., 2018). Formasi Kanikeh merupakan batuan sedimen tertua yang terdapat di Cekungan Bula (Tjokrosapoetro dan Budhitrisna, 1982). Formasi ini terdiri atas batuan silisiklastik yang menindih secara tidak selaras batuan metamorf yang lebih tua serta dijumpai kontak sesar dengan batuan yang lebih tua (Gafoer dkk., 1993). Formasi Kanikeh tersusun atas perselingan batupasir dan serpih yang tersebar di Pulau Seram hingga Pulau Kesui dan Teor di Maluku Tenggara (Wahyudiono dkk., 2018b).

Formasi Kanikeh berumur Trias Akhir-Jura Bawah disebut juga Wakuku Beds oleh AudleyCharles dkk. (1979). Menurut Audley-Charles dkk. (1979) Wakuku beds yang dijumpai pada Wei (sungai) Wakuku dicirikan dengan struktur sedimen laminasi gelembur gelombang, dan kaya akan bioturbasi, tersusun atas seri batuan silisiklastik abu-abu gelap dan terendapkan di lingkungan laut dalam. Menurut O’Sullivan dkk. (1985) formasi ini tersusun atas perselingan batupasir kuarsa hingga litik, berukuran butir pasir halus hingga sedang, karbonan, mikaan, dan glaukonitik yang terendapakan pada umur Mesozoikum di lingkungan transisi hingga laut dangkal. Serpih Formasi Kanikeh berwarna abuabu sedang hingga gelap, batubaraan, dan mengandung berbagai macam mikro fauna yang sama dengan mikro fauna yang berasal dari Australia Utara (Price, 1976 dalam Kemp dan Mogg, 1992). Di daerah Seram Bagian Tengah dan Seram Bagian Timur terdapat singkapan Formasi Kanikeh yang menunjukkan adanya lapisan batupasir dengan stuktur sedimen normal gradasi bersusun, silang-siur, konvolut, laminasi bergelombang, struktur lidah api, struktur pembebanan, tikas seruling, dan lapisan menyerupai flaser (Kemp dan Mogg, 1992). Menurut Gafoer dkk. (1993), "Formasi Kanikeh merupakan sedimen tipe "flysch" atau turbidit terdiri dari perulangan batupasir, batulanau, dan batulumpur”.

Penamaan Formasi Kanikeh secara resmi oleh Pusat Penelitian dan Pengembangan Geologi (Suwitodirjo dkk., 1983). Formasi Kanikeh tersusun atas batuan silisiklastik berukuran halus hingga kasar, adakala berupa konglomerat, batupasir litik arenit, dan batupasir feldspatik litik arenit yang bergradasi dan berselingan dengan batulanau dan batulumpur. Pada Formasi Kanikeh juga terdapat sisipan kalkarenit, kalsilutit, batugamping serpih, dan batupasir karbonatan (Kemp dan Mogg, 1992). Komposisi fragmen litik tersusun atas batuan vulkanik, beku, metamorf dan batuan sedimen dengan dominasi fragmen vulkanik di Seram bagian tengah dibandingkan dominasi fragmen feldspar dan campuran berbagai jenis litik di daerah Bula yang posisinya relatif ke timur (Siemers, 1991 dalam Kemp dan Mogg, 1992).

Studi palinostratigrafi Formasi Kanikeh telah dilaksanakan oleh beberapa peneliti (Helby dkk 1987; Kemp dan Mogg, 1992; Martini dkk., 2004; Chandra dan Kusworo, 2019), hasil dari penelitian tersebut menyatakan umur formasi ini adalah Trias hingga Jura.

Chandra dan Kusworo (2019), mengintrepretasi lingkungan pengendapan Formasi Kanikeh berdasarkan kumpulan palinomorf yang ditemukan dari daerah Lofin, Niner, Oseil dan Bula. Terdapat enam kumpulan palinomorf dari yang paling tua hingga yang termuda adalah kumpulan palinomorf A, B, C, D, E, F. Lingkungan pengendapan kumpulan palinomorft A menunjukkan lingkungan intertidal sedangkan kumpulan palinomorft yang lainnya terendapkan pada lingkungan supratidal. Helby dkk. (1987) menemukan palinomorf Sverdrupiella yang berasosiasi dengan Heibergella pada formasi Kanikeh yang terendapkan di lingkungan laut dangkal.

Interpretasi lingkungan pengendapan pada Formasi Kanikeh masih ada perbedaan (Tabel 1). Tujuan penelitian ini adalah mengetahui lingkungan pengendapan Formasi Kanikeh berdasarkan data pengukuran penampang stratigrafi terbaru. Pengukuran penampang stratigrafi dalam penelitian ini dilakukan menggunakan pendekatan analisis litofasies dan asosiasi fasies pada empat lintasan pengamatan (Gambar 1).

\section{LOKASI PENELITIAN}

Lokasi penelitian terletak di Pulau Seram bagian timur. Kegiatan ini merupakan bagian dari penelitian stratigrafi Cekungan Bula yang dilakukan oleh Tim Pusat Survei Geologi, Badan 
Geologi, Bandung. Kegiatan lapangan tersebut meneliti semua formasi batuan yang terdapat di Seram bagian timur hingga ke Pulau Teor. Dalam artikel ini tidak menggunakan seluruh titik pengamatan pada kegiatan tersebut, lokasi pengamatan yang dipilih hanya lokasi yang telah diidentifikasi merupakan singkapan Formasi Kanikeh. Pemilihan lokasi dalam penelitian ini berdasarkan peta geologi regional dan survei pendahuluan, hasilnya menunjukkan adanya jalur akses yang bisa dilalui untuk mencapai singkapan Formasi Kanikeh di pedalaman Pulau Seram. Terdapat empat lintasan pengamatan Formasi Kanikeh yang dilakukan yaitu Lintasan Lofin $\left(129^{\circ} 54^{\prime} 00^{\prime \prime}-129^{\circ} 57^{\prime} 00^{\prime \prime}\right.$ BT dan 03 03'00'$03^{\circ} 09^{\prime} 00^{\prime \prime}$ LS), yaitu KW26, KW27, KW28, dan KW29. Pada Lintasan Niner (130 09'00"$130^{\circ} 12^{\prime} 00^{\prime \prime}$ BT dan $03^{\circ} 12^{\prime} 00^{\prime \prime}-03^{\circ} 15^{\prime} 00^{\prime \prime}$ LS) telah dilakukan pengamatan pada 2 titik lokasi pengamatan (KW23 dan KW24). Lintasan Oseil $\left(130^{\circ} 36^{\prime} 30,0^{\prime \prime} \quad\right.$ BT dan $03^{\circ} 18^{\prime} 29,1^{\prime \prime}$ LS) merupakan lintasan dengan satu lokasi pengamatan (KW17) di area pengeboran sumur Oseil 2. Pada Lintasan Bula $\left(130^{\circ} 28^{\prime} 34.3^{\prime \prime}\right.$ $130^{\circ} 30^{\prime} 33.2^{\prime \prime}$ BT dan $3^{\circ} 06^{\prime} 28.9^{\prime \prime}-3^{\circ} 07^{\prime} 30.9^{\prime \prime}$ LS) telah dilakukan pengamatan pada 3 titik lokasi pengamatan (KW12, KW13, dan KW14). Penelitian ini didasarkan atas hasil pengamatan singkapan batuan yang ada di daerah tersebut (Gambar 1).

\section{METODE}

Metode yang dilakukan adalah pengukuran penampang stratigrafi menggunakan pendekatan analisis litofasies dan asosiasi fasies. Pengukuran penampang stratigrafi telah dilakukan di daerah Bula, Oseil, Niner, dan Lofin. Studi pustaka merupakan tahapan awal penelitian ini, yang meliputi kajian pustaka yang telah dipublikasi. Hal ini dilakukan untuk memahami gambaran awal mengenai kondisi geologi, lokasi pengamatan singkapan, dan mengetahui permasalahan yang ada dalam formasi ini, yaitu adanya interpretasi lingkungan pengendapan yang berbeda-beda. Analisis peta geologi dan peta topografi daerah penelitian juga dilaksanakan sebelum kegiatan lapangan. Setelah melakukan kajian pustaka dilakukan survei pendahuluan untuk mengetahui askses jalan dan kondisi singkapan batuan yang akan menjadi target penelitian. Lintasan geologi yang dipilih berupa lintasan jalan, sungai, dan tebing supaya mendapat singkapan yang baik. Data utama yang dikumpulkan meliputi pengukuran penampang stratigrafi dan dokumentasi.

Pengukuran penampang stratigrafi dilakukan untuk dapat mengetahui sifat fisik dari batuan. Pengukuran tersebut berguna untuk mengetahui sebaran dan panjang dari setiap satuan batuan. Tahapan selanjutnya adalah analisis studio, dilakukan determinasi jenis litofasies setiap batuannya kemudian diklasifikasikan asosiasi

Tabel 1. Rangkuman hasil interpretasi lingkungan pengendapan Formasi Kanikeh dari peneliti sebelumnya.

\begin{tabular}{|c|c|c|c|}
\hline No. & Peneliti & Metode & $\begin{array}{l}\text { Interpretasi Lingkungan } \\
\text { Pengendapan }\end{array}$ \\
\hline 1 & $\begin{array}{l}\text { Audley-Charles dkk. } \\
\text { (1979) }\end{array}$ & $\begin{array}{llll}\begin{array}{l}\text { Pengamatan } \\
\text { Wakuku }\end{array} & \text { lapangan } & \text { di } & \text { Sungai } \\
\end{array}$ & Laut dalam \\
\hline 2 & Gafoer (1993) & Pemetaan geologi & Laut dalam \\
\hline 3 & $\begin{array}{l}\text { Kemp dan Mogg } \\
\text { (1992) }\end{array}$ & Pengamatan lapangan & Laut dalam \\
\hline 4 & $\begin{array}{l}\text { Tjokrosapoetro dan } \\
\text { Budhitrisna (1982) }\end{array}$ & Pemetaan geologi & Neritik hingga laut dalam \\
\hline 5 & $\begin{array}{l}\text { O’Sullivan dkk. } \\
\text { (1985) }\end{array}$ & Pengamatan lapangan & Transisi hingga laut dangkal \\
\hline 6 & Helby dkk. (1987) & Studi palinologi & Laut dangkal \\
\hline 7 & $\begin{array}{l}\text { Chandra dan Kusworo } \\
\text { (2019) }\end{array}$ & Studi palinologi & Supratidal \\
\hline
\end{tabular}




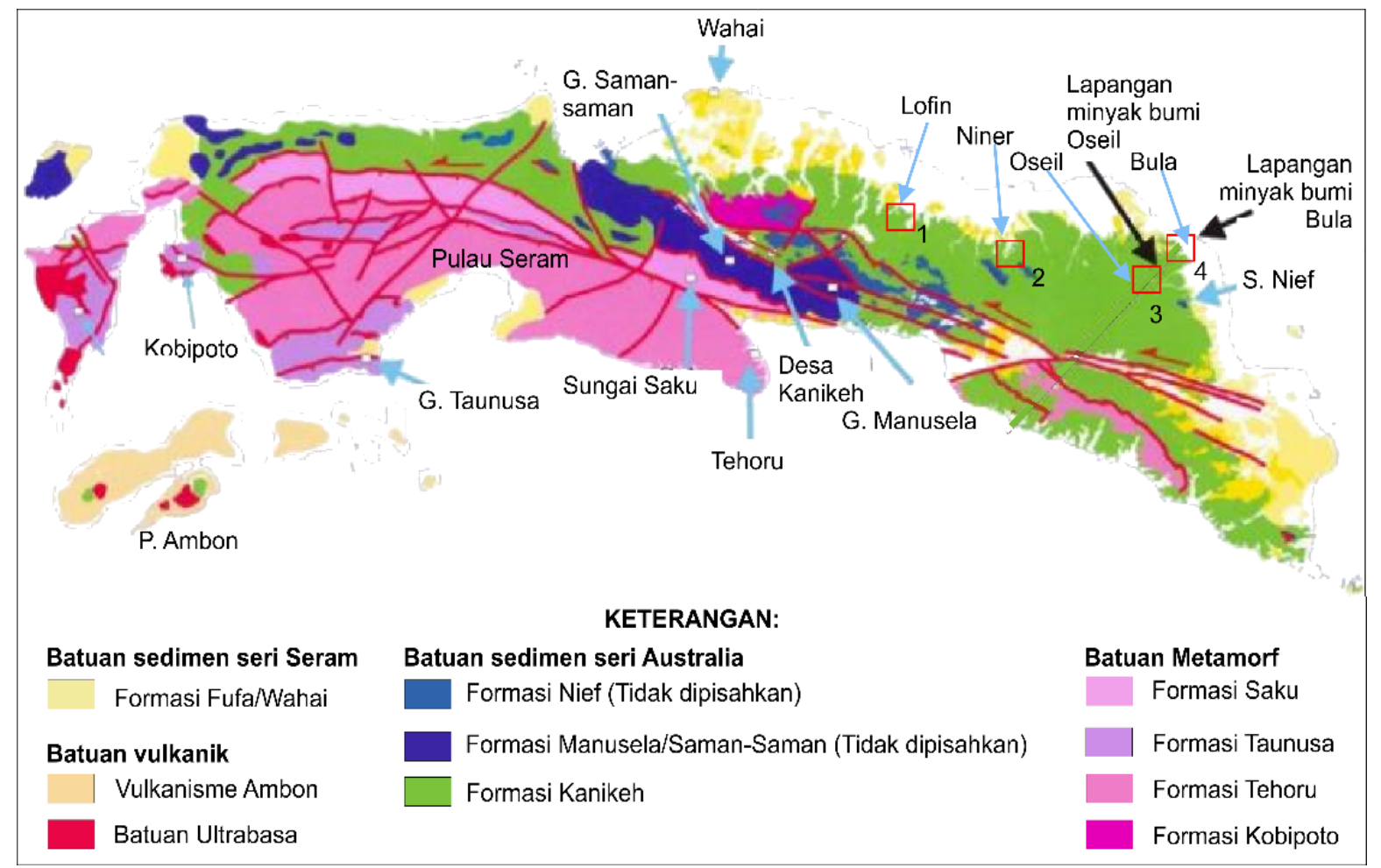

Gambar 1. Peta Geologi Pulau Seram (Modifikasi Hill, 2012). Kotak berwarna merah merupakan lokasi penelitian, (1) Lintasan Lofin, (2) Lintasan Niner, (3) Lintasan Oseil, dan (4) Lintasan Bula.

fasiesnya sehingga dapat diinterpretasikan proses sedimentasinya hingga lingkungan pengendapannya.

Menurut Walker dan James (1992), litofasies adalah suatu rekaman stratigrafi pada batuan sedimen yang menunjukkan karakteristik fisika, kimia, dan biologis tertentu yang berbeda dengan batuan diatas, dibawah ataupun dengan persebaran lateralnya sehingga dapat digunakan untuk menginterpretasikan kondisi pengendapan, sejarah geologi, dan menjelaskan hubungan geometri di antara unit batuan.

Analisis litofasies dilakukan dengan menentukan karakteristik, mengelompokkan dan menamakan litofasies dengan mengacu kepada klasifikasi yang dikemukakan oleh Miall (1978 dalam Walker dan James, 1992), dan menambahkan beberapa litofasies yang teramati.

Asosiasi fasies adalah sekelompok fasies yang secara genesa berhubungan antara satu dan yang lainnya, yang memiliki lingkungan pembentukan yang sama (Walker dan James, 1992).

\section{HASIL}

Berikut adalah penjelasan dari setiap lintasan pengamatan:

\section{Lintasan Lofin}

Lintasan Lofin terletak disebelah Timur Kecamatan Bula, lintasan ini merupakan lintasan jalan, lokasi pengeboran (wellpad) sumur Lofin 2 dan lintasan sungai. Berdasarkan pengamatan lapangan, singkapan batuan di Lintasan Lofin terdiri dari batupasir konglomeratan, batupasir, batulumpur karbonan, dan batulumpur bernodul oksida besi. Komposit log lintasan lofin terdapat pada Gambar 2.

\section{Lintasan Niner}

Lintasan Niner terletak di sebelah selatan Desa Jakarta Baru. Lintasan ini merupakan lintasan jalan perintis yang menghubungkan Desa Jakarta Baru dengan Kecamatan Werinama. Berdasarkan pengamatan lapangan, singkapan batuan di Lintasan Niner terdiri dari batupasir dan 
batulumpur. Komposit log litologi yang dijumpai pada Lintasan Niner tergambar pada Gambar 2.

\section{A. Lintasan Lofin}

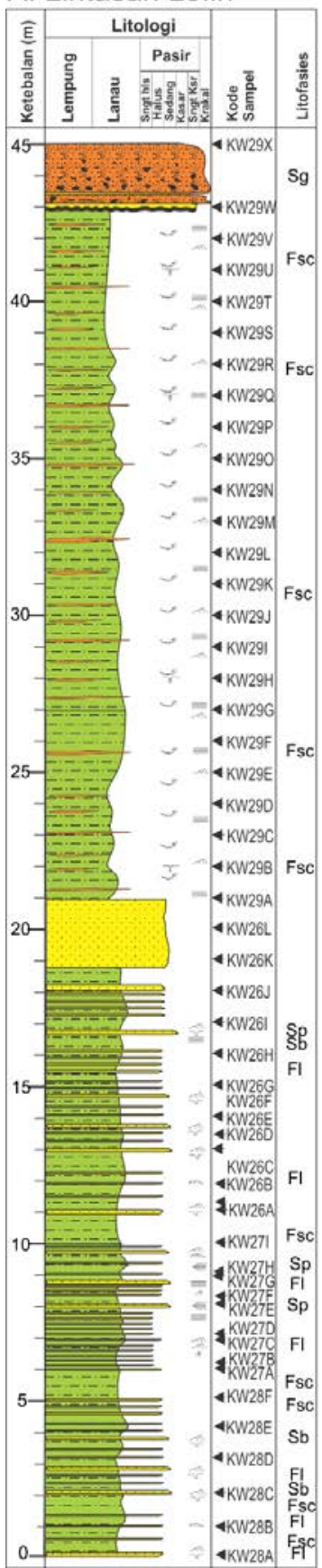



\section{Lintasan Oseil}

Lintasan Oseil terletak di sebelah selatan Kecamatan Bula. Singkapan batuan di lokasi tersebut terdiri dari perselingan batupasir dan
C. Lintasan Oseil

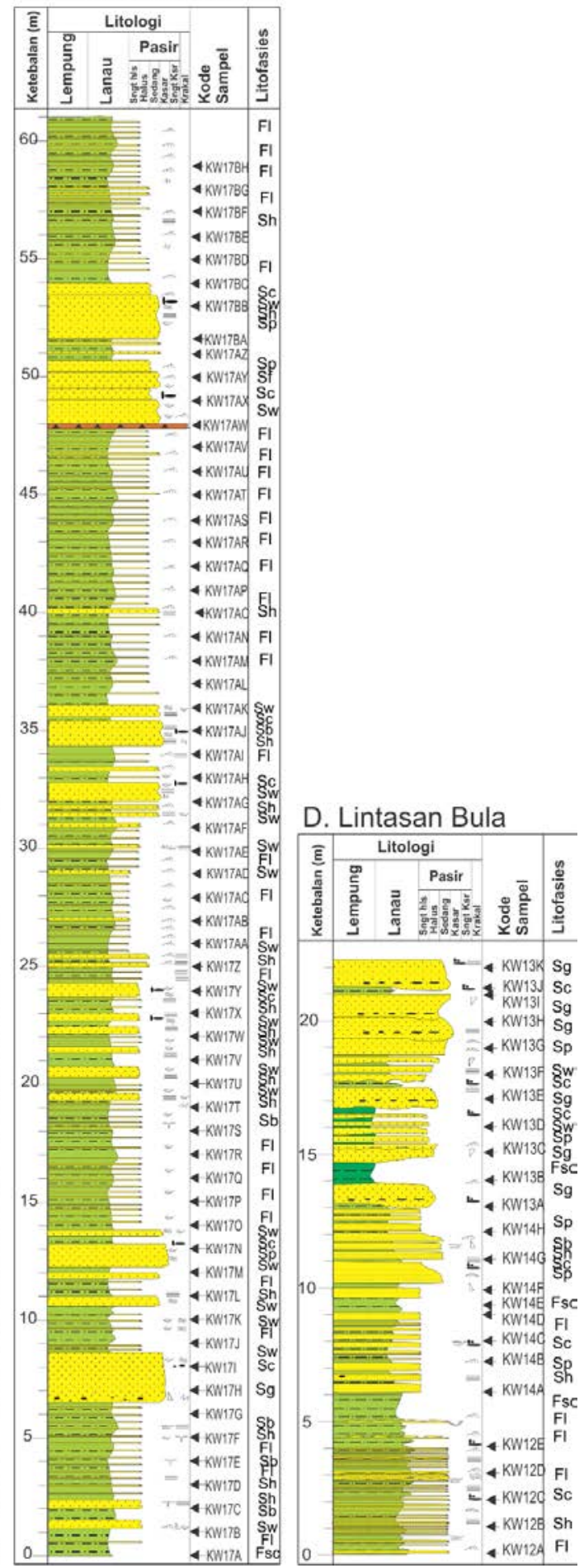

Gambar 2. Profil litologi Lintasan Lofin, Niner, Oseil dan Bula 
batulumpur. Komposit log litologi yang dijumpai pada Lintasan Oseil tergambar pada Gambar 2.

\section{Lintasan Bula}

Lintasan Bula terletak di sekitar Kecamatan Bula. Lokasi singkapan terdekat Bula terletak di sungai Weilola Kecil dan Kalimati. Berdasarkan pengamatan lapangan, singkapan batuan di Lintasan Bula terdiri dari perselingan batupasir dan batulumpur hingga menjadi batupasir berlapis tebal. Komposit log lintasan Bula tergambar pada Gambar 2.

\section{Litofasies}

Hasil pengukuran penampang stratigrafi memperlihatkan adanya sembilan jenis litofasies yaitu:

- Litofasies Batupasir Konglomeratan (Sg)

- Litofasies Batupasir Lapisan Silangsiur Mangkok (Sp)

- Litofasies Batupasir Bioturbasi (Sb)

- Litofasies Batupasir Karbonan (Sc)

- Litofasies Batupasir Bergelombang (Sw)

- Litofasies Batupasir Flaser (Sf)

- Litofasies Batupasir Laminasi Sejajar (Sh)

- Litofasies Batulumpur Lentikuler (Fl)

- Litofasies Batulumpur Berlapis (Fsc)

\section{Litofasies Batupasir Konglomeratan (Sg)}

Litofasies ini ditemukan pada lintasan Lofin, Niner, Oseil, dan Bula. Batupasir Konglomeratan berfragmen batulumpur dan batulanau, warna abu- abu terang, karbonatan, dengan matriks batupasir kasar. Matriks tersebut memiliki ciri fisik yang sama dengan lapisan batupasir di bawah dan atasnya. Matrik batupasir kasar, berwarna abu-abu terang, kemas terbuka, pemilahan buruk, ukuran butir pasir kasar, kompak. Terdapat gradasi ukuran butir menjadi batupasir halus yang kaya material karbon, membentuk struktur sedimen laminasi sejajar di bagian atas litofasies Sg. Kontak litofasies Sg adalah kotak gradasi di bagian atas, dan kontak erosional di bagian bawah (Gambar 3). Ketebalan lapisan lebih dari 0,5 meter, konglomerat ini secara lateral dapat diikuti kemenerusannya lebih dari 10 meter.

\section{Litofasies Batupasir Silang-Siur Mangkok (Sp)}

Litofasies Batupasir Silang-Siur Mangkok (Sp) ditemukan pada Lintasan Lofin, Niner, Oseil, dan Bula. Karakter fisiknya batupasir berwarna abuabu terang, terpilah baik, ukuran butir pasir sedang-kasar, abu-abu kecoklatan, non karbonatan, terdapat fragmen mika halus, dan material karbon. Material karbon yang membentuk struktur sedimen silang-siur mangkok dan tikas seruling di bagian dasar lapisan (Gambar 4). Kontak erosional di bagian bawah litofasies. Ketebalan litofasies Sp berkisar antara 0,5 hingga 1 meter.


Gambar 3. A. Foto singkapan litofasies batupasir konglomeratan pada Lintasan Lofin, kotak merah merupakan posisi foto B; B. Foto detail lapisan litofasies konglomeratan, panah menunjukkan fragmen batulumpur dan batulanau, garis kuning merupakan bidang erosi pada bagian bawah lapisan. 

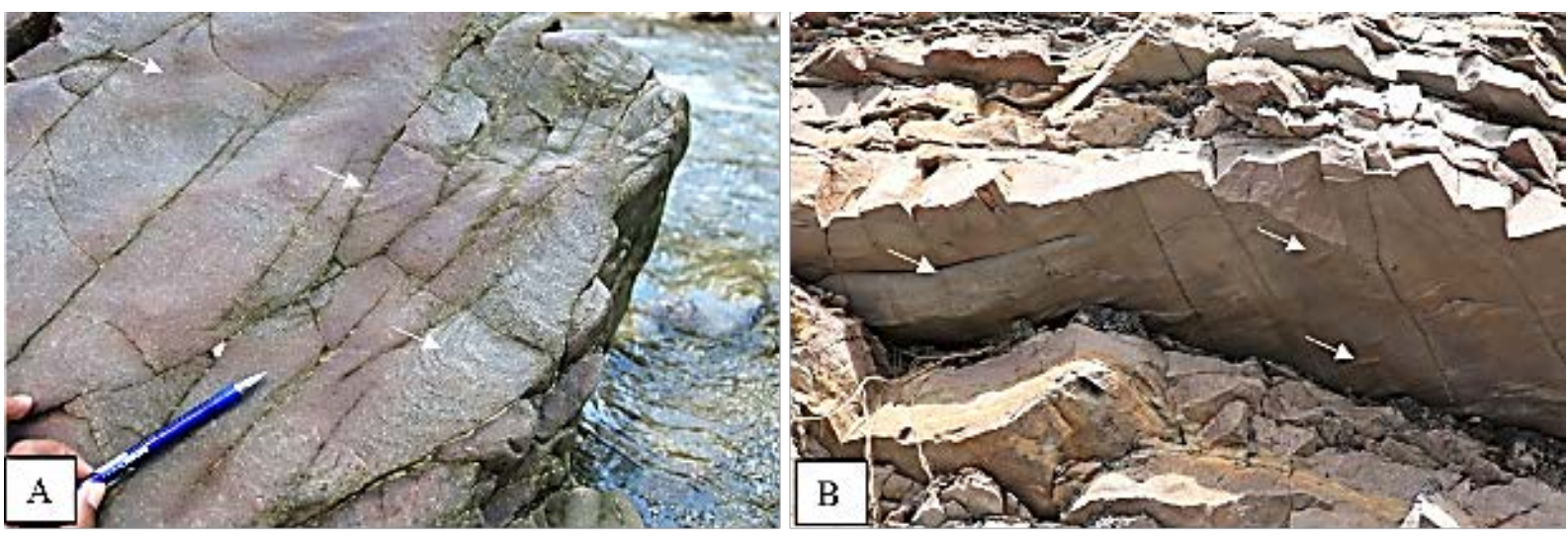

Gambar 4. A. Foto litofasies Batupasir Silang-Siur Mangkok (Sp) ditunjukkan pada panah warna putih, ditemukan di Lintasan Lofin; B. Foto Litofasies Batupasir Silang-Siur Sejajar (Sp), ditemukan di Lintasan Oseil, panah putih menunjukkan struktur sedimen tikas seruling.
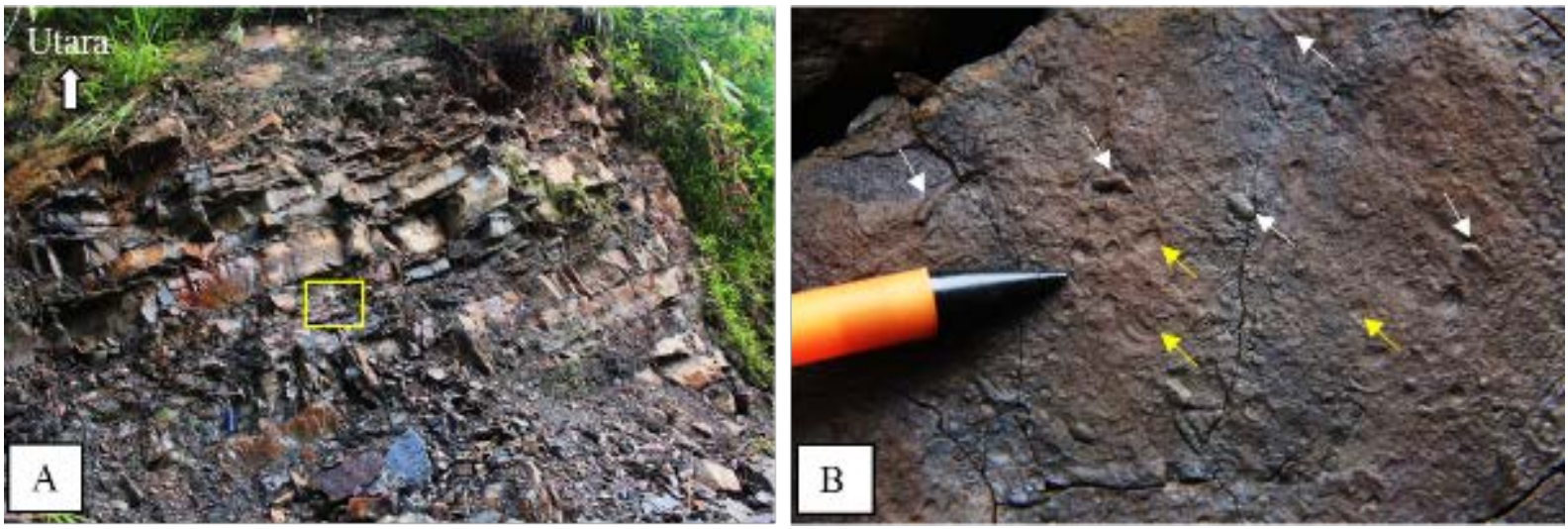

Gambar 5. A. Foto singkapan litofasies batupasir bioturbasi pada Lintasan Niner, kotak kuning merupakan posisi foto B; B. kenampakan bioturbasi (panah putih) dan fragmen moluska tak teridentifikasi (panah kuning) pada litofasies batupasir bioturasi, bioturbasi tersebut terdapat di setiap lapisan batupasir.

\section{Litofasies Batupasir Bioturbasi (Sb)}

Litofasies batupasir bioturbasi ditemukan di Lintasan Lofin, Niner, dan Bula berupa batupasir sedang, abu-abu kecoklatan, non karbonatan, terdapat fragmen mika halus, fragmen moluska tak teridentifikasi, dan material karbon yang membentuk struktur sedimen laminasi sejajar, gelembur gelombang, dan laminasi silang-siur, bioturbasi horizontal (Gambar 5). Ketebalan litofasies ini 0,1 hingga 0,2 m.

\section{Litofasies Batupasir Karbonan (Sc)}

Litofasies ini ditemukan pada Lintasan Lofin, Niner, Oseil, dan Bula, berupa batupasir berlapis sedang (tebal 0,1-1,8 $\mathrm{m}$ ) dengan sisipan batulumpur (tebal 0,03-0,05 m). Batupasir, warna abu-abu, non karbonatan, kaya fragmen mika dan material karbon yang berupa fragmen batubara maupun membentuk struktur laminasi sejajar, laminasi silang-siur dan gelembur gelombang. Pada batupasir juga banyak mengandung fosil moluska yang sangat melimpah, berupa lembaranlembaran tipis yang searah dengan lapisan. Jenis moluska yang diidentifikasi dalam lapisan batupasir adalah Halobia (Zittelihalobia) superba (Mojsisovic, 1874) (Gambar 6).

\section{Litofasies Batupasir Laminasi Bergelombang (Sw)}

Litofasies batupasir laminasi bergelombang ditemukan pada Lintasan Bula berupa batupasir berlapis sedang $(0,1-0,2 \mathrm{~m})$, batupasir, warna abu- 

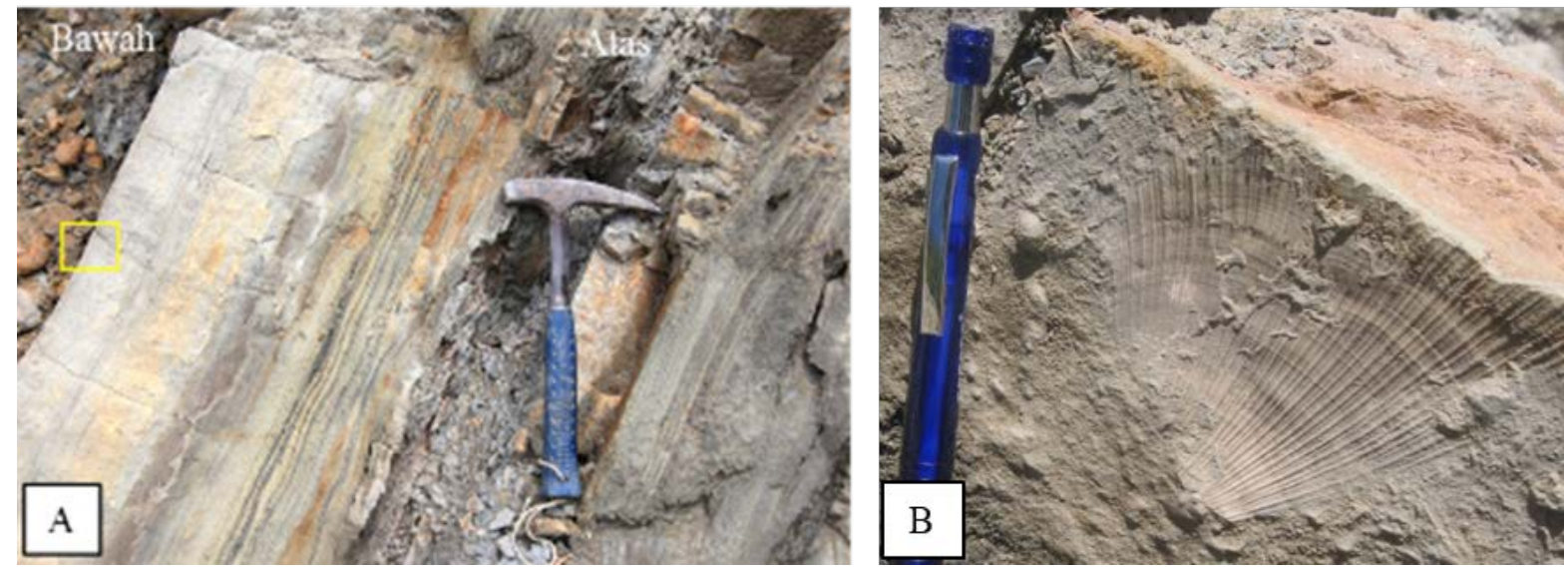

Gambar 6. A. Foto singkapan litofasies batupasir karbonan pada Lintasan Bula, dengan kondisi lapisan sudah terbalik, kotak kuning merupakan posisi foto B; B. Foto detail menunjukkan fragmen cangkang Halobia (Zittelihalobia) superba (Mojsisovic, 1874) pada bagian bawah lapisan batupasir karbonan.

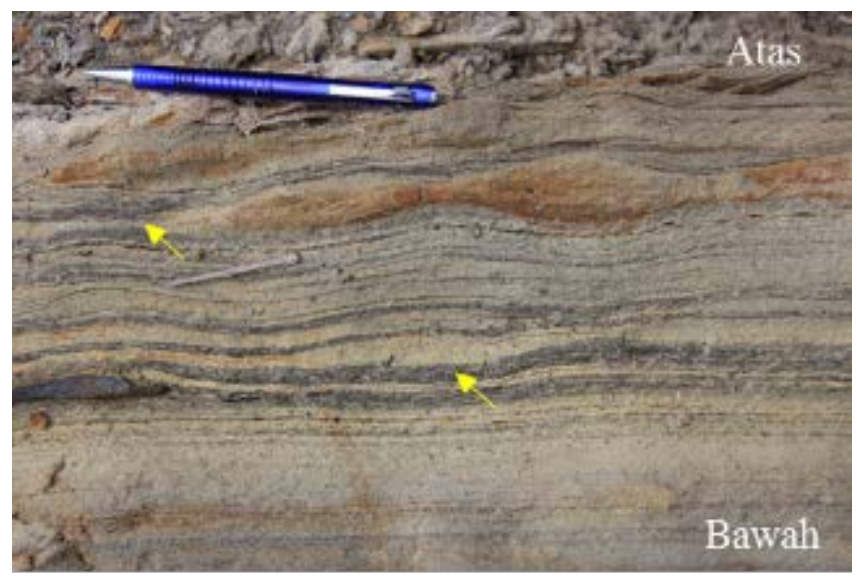

Gambar 7. Foto singkapan Litofasies Batupasir Bergelombang (panah kuning).

abu, non karbonatan, kaya fragmen mika dan karbon, terdapat struktur sedimen laminasi bergelombang dan gelembur gelombang (Gambar 7).

\section{Litofasies Batupasir Flaser (Sf)}

Litofasies batupasir flaser ditemukan pada Lintasan Lofin dan Bula berupa batupasir berlapis tipis (0,005-0,08 m), warna abu-abu, non karbonatan, kaya fragmen mika, struktur sedimen lapisan flaser (Gambar 8). Pada batupasir juga banyak mengandung fosil moluska yang sangat melimpah, berupa lembaran-lembaran tipis yang searah dengan lapisan, jenis moluska yang diidentifikasi adalah Halobia sp.

\section{Litofasies Batupasir Laminasi Sejajar (Sh)}

Litofasies batupasir laminasi sejajar ditemukan pada Lintasan Lofin, Niner, Oseil, dan Bula berupa batupasir warna abu-abu terang, non karbonatan, pemilahan baik, membundar, tertutup, banyak dijumpai mineral mika, carbon string, dengan struktur sedimen laminasi sejajar, sangat 


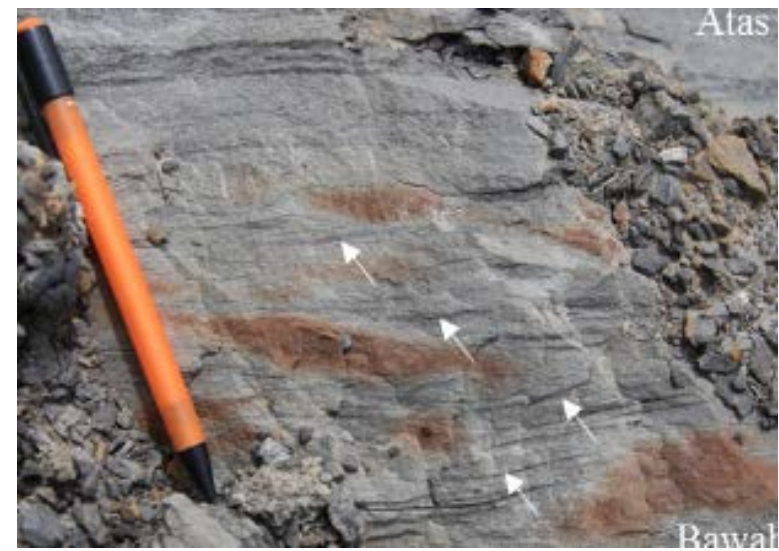

Gambar 8. Foto singkapan litofasies batupasir flaser pada Lintasan Lofin.
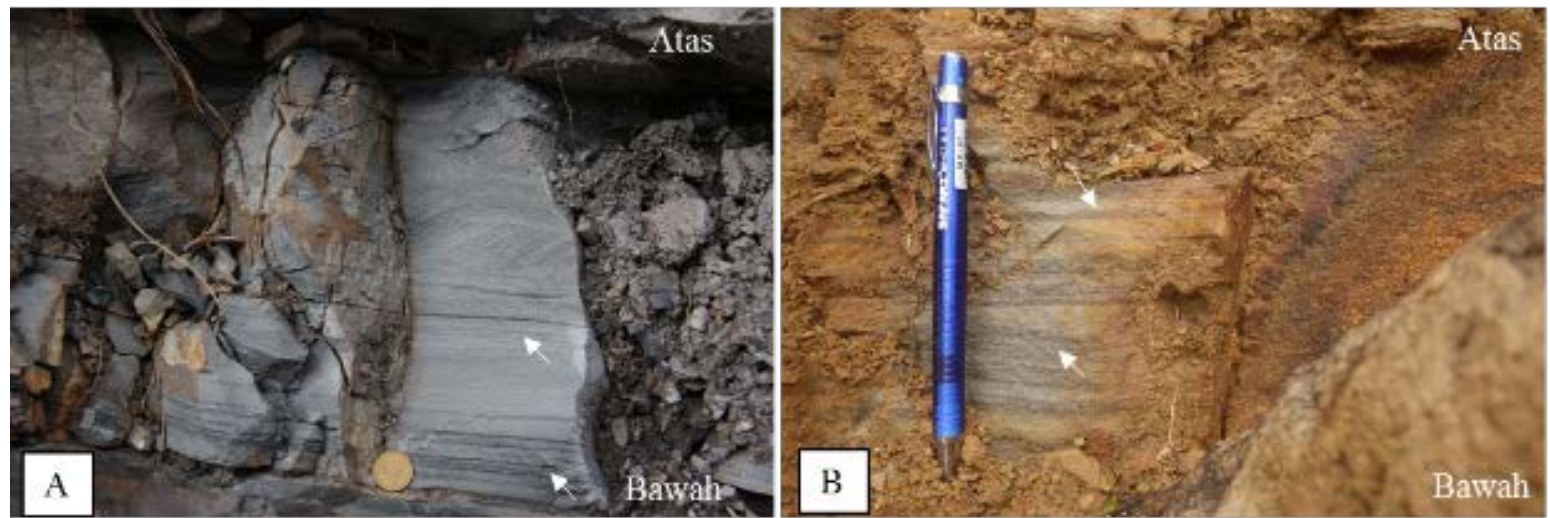

Gambar 9. A. Foto singkapan litofasies batupasir laminasi sejajar (panah putih) pada Lintasan Oseil; B. Foto singkapan litofasies batupasir laminasi sejajar (panah putih) pada lintasan Nine.
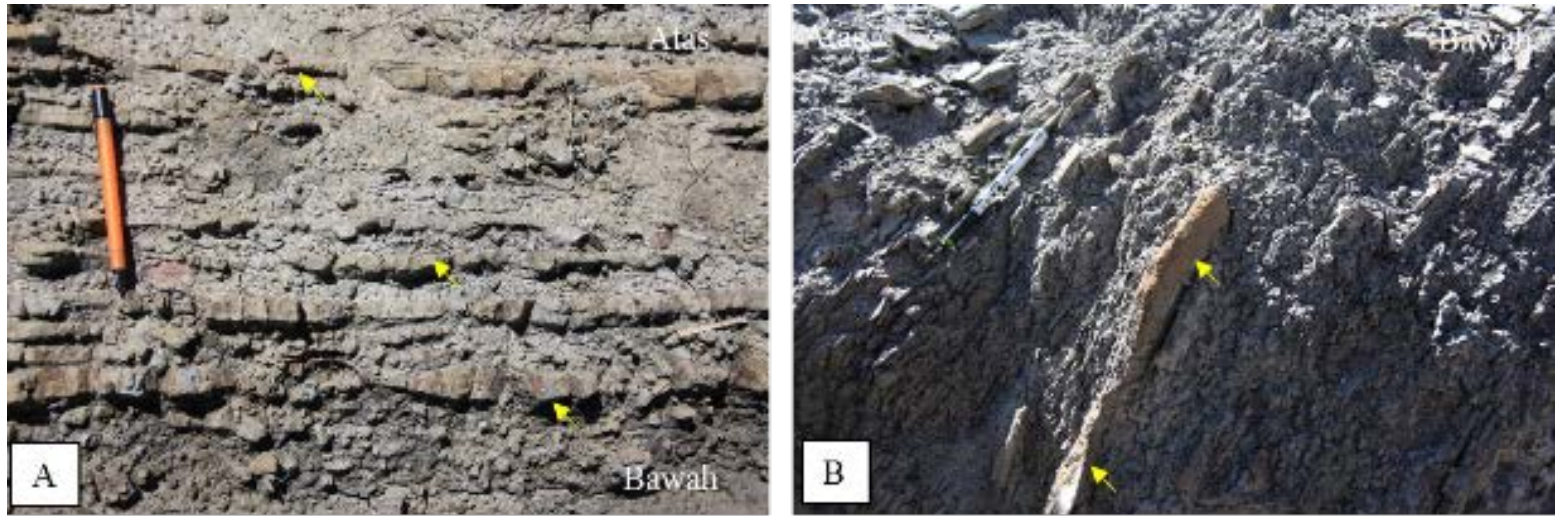

Gambar 10. A. Foto singkapan fasies Fl (panah kuning) pada Lintasan Bula; B. Foto singkapan fasies Fl (panah kuning) pada Lintasan Lofin.

kompak (Gambar 9). Ketebalan fasies ini berkisar antara 0,05-0,1 m.

\section{Litofasies Batulumpur Lentikuler (FI)}

Litofasies Fl ditemukan pada Lintasan Lofin, Oseil, dan Bula berupa batulumpur berwarna abuabu gelap, getas, non karbonatan, dengan struktur 


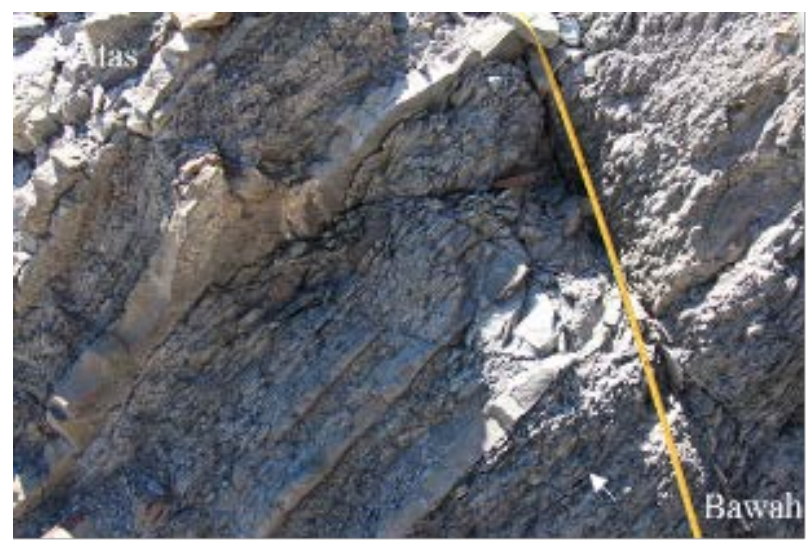

Gambar 11. Foto singkapan fasies Fsc (panah putih) pada Lintasan Lofin.

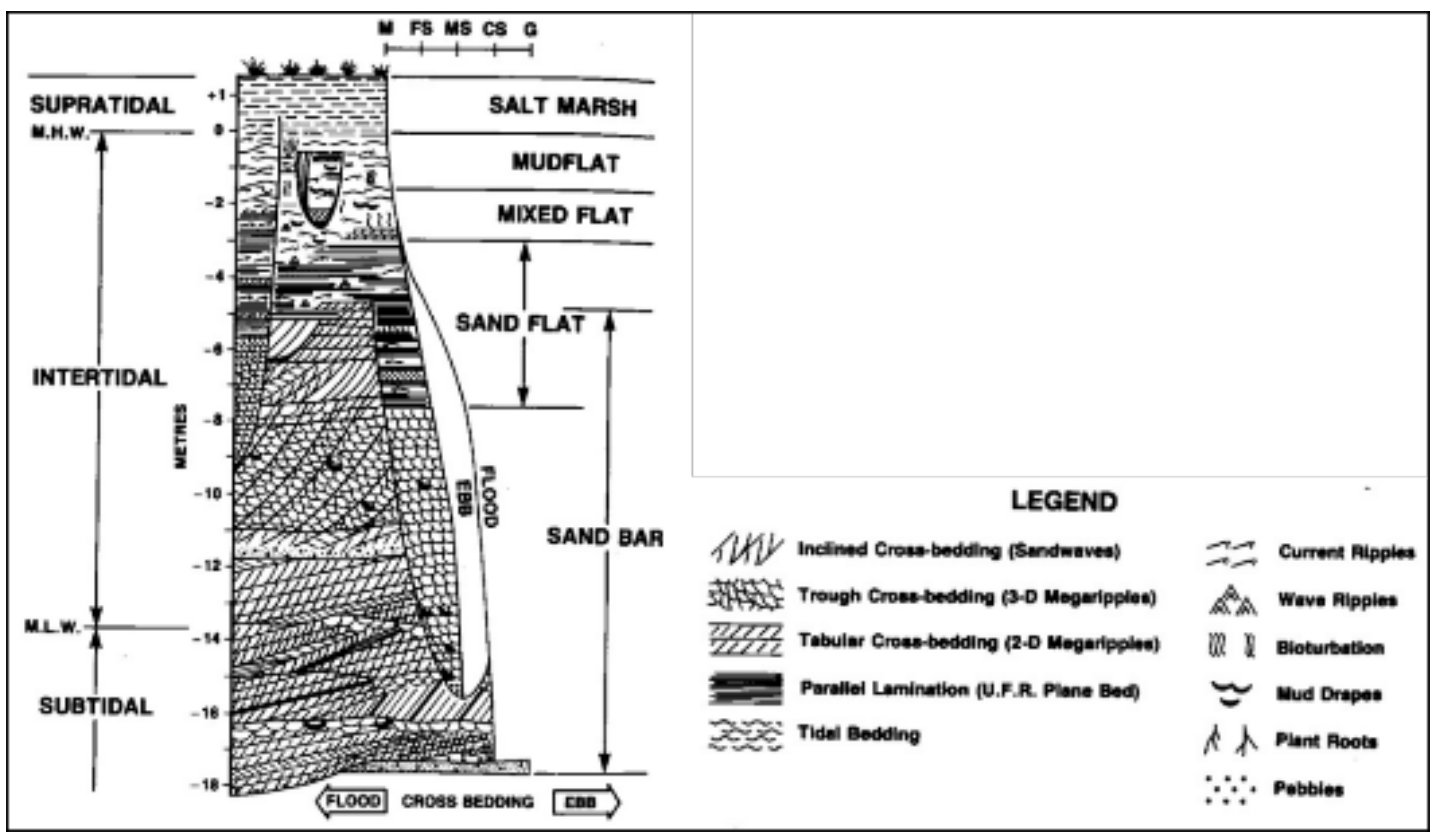

Gambar 12. Suksesi vertikal estuary yang dipengaruhi oleh sistem pasang-surut secara ideal (Dalrymple dkk., 1990).

sedimen lentikuler batupasir halus (Gambar 10). Litofasies ini memiliki ketebalan 0,03-0,05 m.

\section{Litofasies Batulumpur Berlapis (Fsc)}

Litofasies Fsc ditemukan pada Lintasan Lofin, Oseil, dan Bula berupa batulumpur berwarna abuabu gelap, getas, berlapis dengan ketebalan $0,02-$ $0,03 \mathrm{~cm}$ (Gambar 11). Litofasies ini memiliki ketebalan 0,5-2 m.

\section{Asosiasi Fasies}

Dari hasil analisis litofasies yang telah dilakukan, ditemukan beberapa kenampakan sedimen yang merupakan penciri dari suatu endapan pasangsurut (Gambar 12) yaitu:

- Flaser, lapisan bergelombang, lapisan lentikuler (Reineck dan Wunderlich, 1968; Shanmugam dkk., 1998)

- Lapisan silang siur dengan endapan mud-drape (Terwindt, 1981; Shanmugam dkk., 1998) 
Perselingan tebal-tipis lanau-lempung yang membentuk ritme teratur/ritmis (Kuecher dkk., 1990; Shanmugam dkk., 1998).

Analisis asosiasi fasies Formasi Kanikeh terutama yang diamati pada studi ini dapat dibagi menjadi empat asosiasi fasies yang termasuk ke dalam suatu sistem pengendapan pasang-surut intertidal yaitu tidal channel, tidal sand flat, tidal sand-mud mixed flat, dan tidal mud flat (Gambar 14). Penggambaran diagram blok lingkungan pasang surut digambarkan oleh Dalrymple (1992) (Gambar 13).

\section{Tidal Channel}

Asosiasi fasies tidal channel terdiri dari asosiasi litofasies Sg, Sp, dan Sc, dengan ketebalan siklus sedimentasi 1-2 m. Suksesi vertikal yang ditunjukan menghalus ke atas. Litofasies Sg yang diendapkan pada arus yang cukup kuat merupakan salah satu penciri asosiasi ini, sedangkan litofasies Sp terbentuk akibat adanya dua arah arus, yaitu arus pasang dan surut. Litofasies Sc terbentuk pada saat masa tenang antara pasang dan surut.

\section{Interpretasi:}

Asosiasi fasies tidal channel ditandai dengan kehadiran struktur sedimen silangsiur mangkuk dan silang siur planar. Struktur tersebut mengindikasikan arus pengendapan berupa arus traksi satu arah aliran dengan rezim aliran bagian bawah berturbulensi tinggi yang membentuk struktur dunes dalam berbagai ukuran (Walker dan James, 1992). Adanya fragmen batulumpur di dasar lapisan mengindikasikan selama proses pengendapan terjadi proses erosi lapisan yang berada di bawahnya yang berupa endapan dataran pasang surut. Suksesi vertikal menghalus ke atas mengindikasikan bahwa arus pengendapan sangat cepat di bagian bawah kemudian kelemah di bagian atas (Gambar 14d pada meter ke 19,3 hingga 22,3).

Adanya sisipan batulumpur yang membentuk struktur sedimen bergelombang sampai lentikuler mengindikasikan adanya proses suspended load yang diakibatkan oleh adanya arus pasang yang membawa endapan dengan fraksi sangat halus berupa batulumpur (Walker dan James, 1992). Vertikal dan horizontal bioturbasi yang terdapat

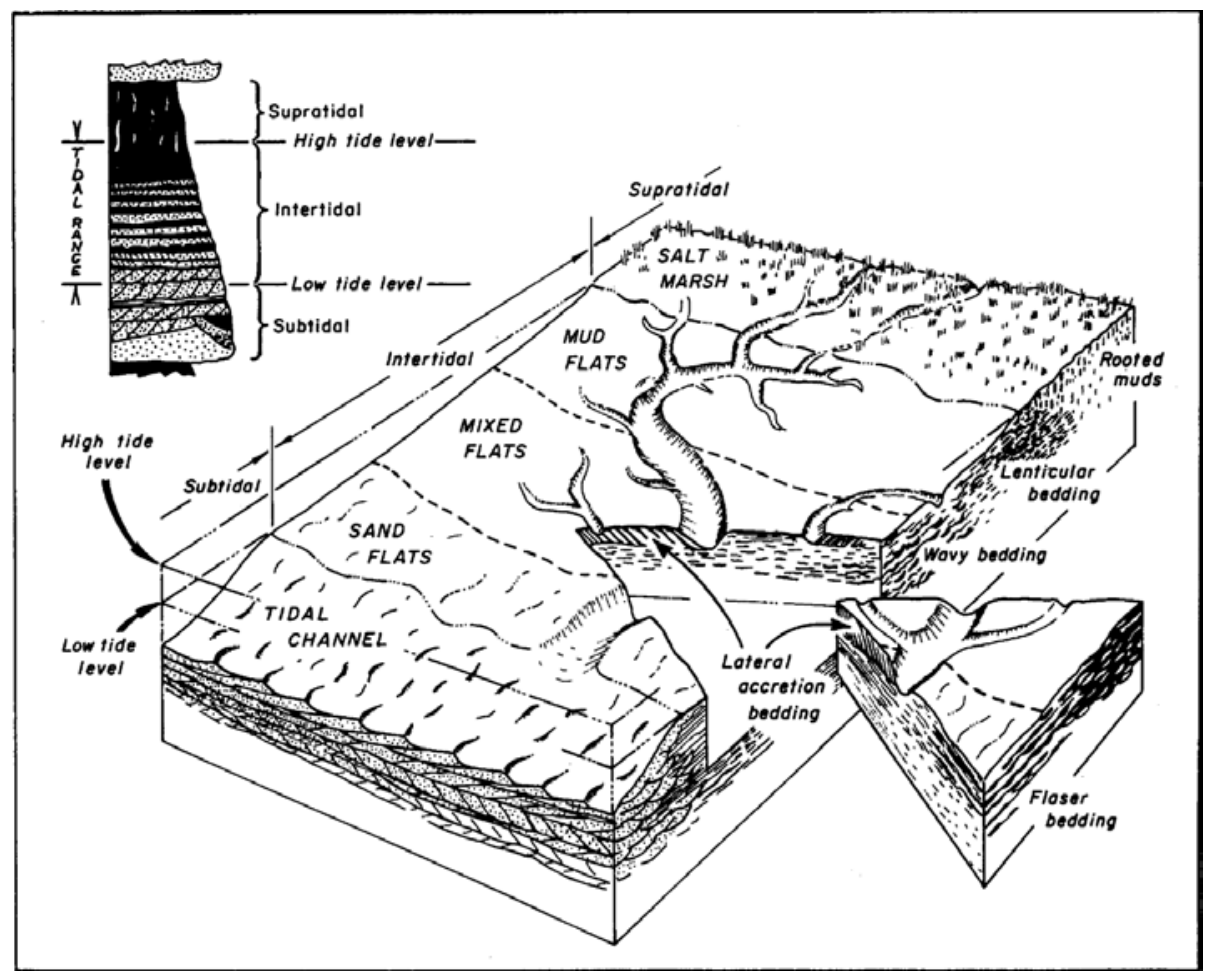

Gambar 13. Diagram blok sistem pengendapan pasang-surut (tidal flats) (Dalrymple, 1992). 
pada asosiasi fasies ini mengindikasikan adanya pengaruh laut. Dari kombinasi litofasies yang muncul tersebut dibuktikan dengan adanya erosi dasar alur aliran maka diinterpretasikan sebagai aliran pasang surut (tidal channel).

\section{Tidal Sand Flat}

Asosiasi fasies tidal sand flat terdiri dari litofasies Sp, Sb, Sc, Sf, dan Sh dengan ketebalan satu siklus sedimentasi 1-2 m. Suksesi vertikal yang ditunjukan menghalus ke atas, dengan litofasies Sf sebagai penciri utama asosiasi fasies ini. Litofasies Sb, Sc, dan Sh muncul di bagian atas dalam suatu siklus sedimentasi. Adanya litofasies Sb menunjukan adanya pengaruh laut dan litofasies Sf mencirikan daerah ini dipengaruhi oleh arus pasang-surut (Gambar 14).

\section{Interpretasi:}

Suksesi vertikal batupasir menghalus ke atas pada asosiasi fasies ini mengindikasikan perubahan energi yang semakin membesar kearah atas, energi yang yang besar ini ditunjukan dengan butiran yang paling kasar di bagian atas lapisan.

Perubahan struktur sedimen dari lentikuler hingga flaser, serta laminasi silang siur diatasnya menunjukkan perubahan kecepatan arus aliran yang semakin cepat kearah atas (Walker dan James, 1992). Laminasi material karbon di bagian laminasi silang siur menunjukkan bahwa suplai sedimen dari darat masih cukup dominan. Kehadiran mud-drape mengindikasikan pada proses pengendapannya, asosiasi fasies ini dipengaruhi oleh arus pasang surut air laut di bagian atasnya dekat dengan garis pasang surut bagian bawah (low tide).

\section{Mixed Tidal Sand-Mud Flat}

Asosiasi fasies mixed tidal sand-mud flat terdiri dari litofasies Sp, Sf, Sw, dan Fl dengan ketebalan satu siklus sedimentasi $0.2-1 \mathrm{~m}$. Suksesi vertikal yang ditunjukan menghalus ke atas, kenampakan struktur sedimen yang terlihat khas dalam asosiasi fasies ini adalah bentukan flaser-lentikuler yang asimetris yang membentuk ritme teratur yang mengindikasikan adanya pengaruh pasang-surut muka laut pada daerah ini. Litofasies Sp terletak di bagian bawah kemudian berubah menjadi litofasies $\mathrm{Sw}$ ke bagian atas. Litofasies Sf mencirikan daerah ini dipengaruhi oleh arus pasang surut (Gambar 14).

\section{Interpretasi:}

Kehadiran struktur flaser dengan kandungan batupasir yang cukup dominan bergradasi menjadi lentikuler di bagian atasnya dengan kandungan batupasir yang semakin berkurang merupakan indikasi perubahan energi yang melemah ke arah atas (Walker dan James, 1992). Kondisi tersebut terdapat pasa suatu daratan yang dipengaruhi oleh arus pasang surut (intertidal). Pada kondisi tersebut arus paling besar terdapat di daerah yang dekat dengan alur pasang surut dan semakin berkurang ke arah daratan (Dalrymple, 1992). Secara keseluruhan, asosiasi fasies ini memiliki suksesi vertikal menghalus ke atas.

\section{Tidal Mud Flat}

Asosiasi fasies tidal mud flat terdiri dari litofasies Fl dan Fsc yang berupa batulumpur berlapis dengan sisipan batulanau, tebal asosiasi fasies ini 1-1,5 m. Lapisan lentikuler umunya ditemukan di lingkungan tidal flat, adanya perulangan lapisan tebal-tipis yang terbentuk antara lanau-lempung yang menunjukkan siklus yang teratur diinterpretasikan sebagai suatu pengaruh dari pasang-surut muka air laut. Lapisan batulanau mewakili endapan arus traksi yang terbentuk ketika pengaruh pasang dan surut sedangkan lapisan lempung mewakili endapan suspensi ketika air tenang (Gambar 14).

\section{Interpretasi:}

Asosiasi fasies ini diinterpretasikan diendapkan pada daerah yang sangat tenang, namun masih terdapat pengaruh baik dari arus laut maupun arus sungai. Biasanya asosiasi fasies ini terletak di atas asosiasi fasies mixed tidal sand-mud flat. 


\section{A. Lintasan Lofin}

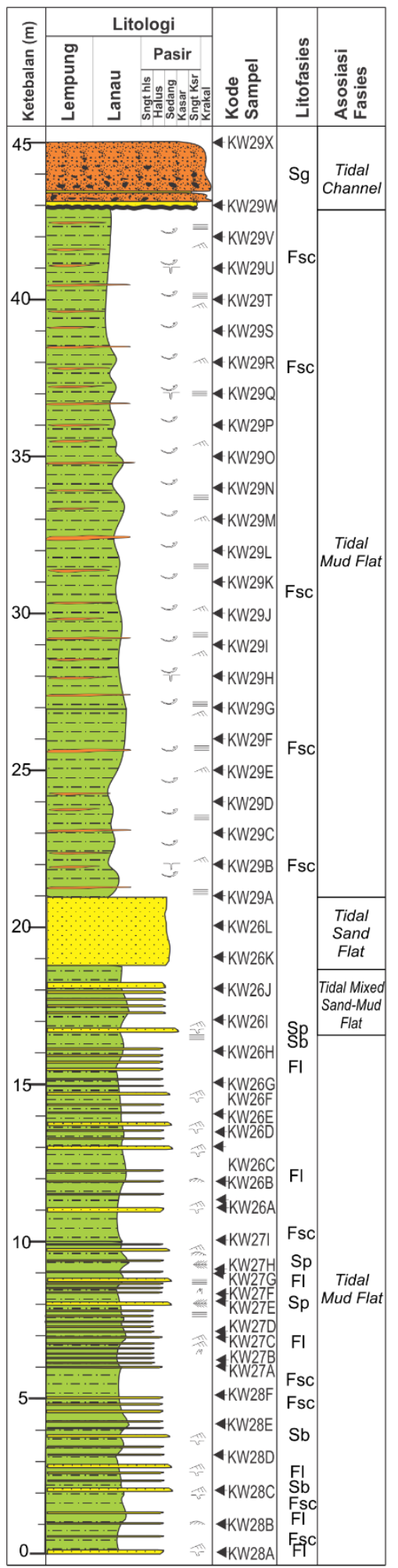

B. Lintasan Oseil

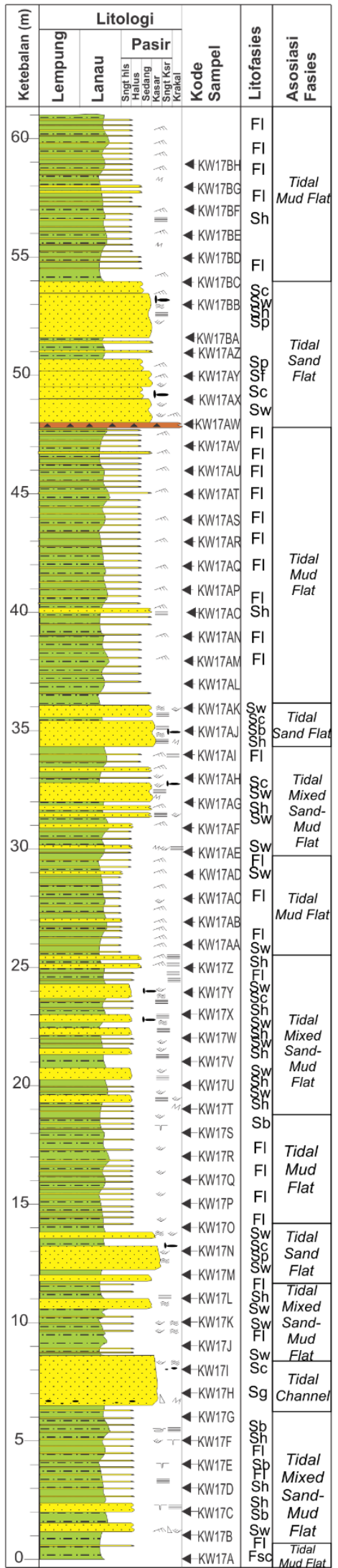

C. Lintasan Niner

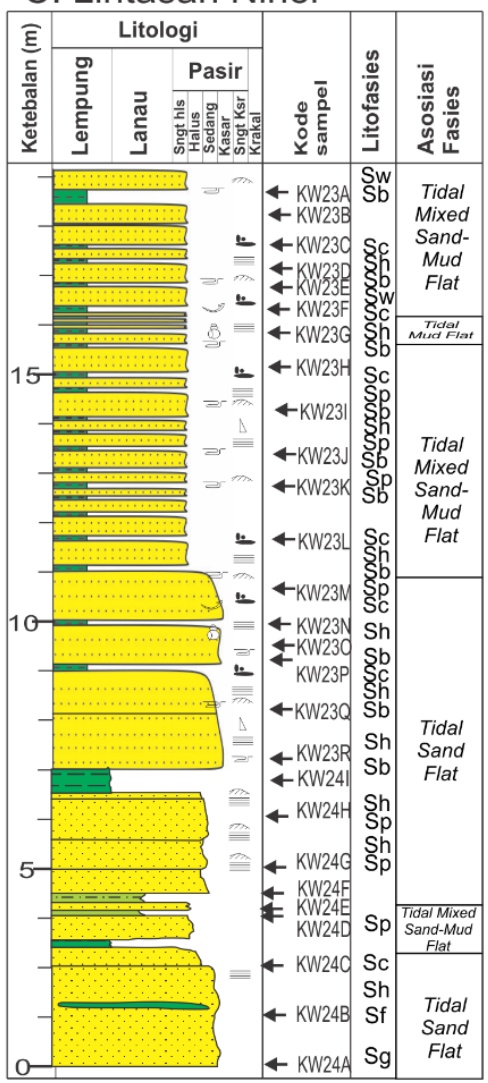

D. Lintasan Bula

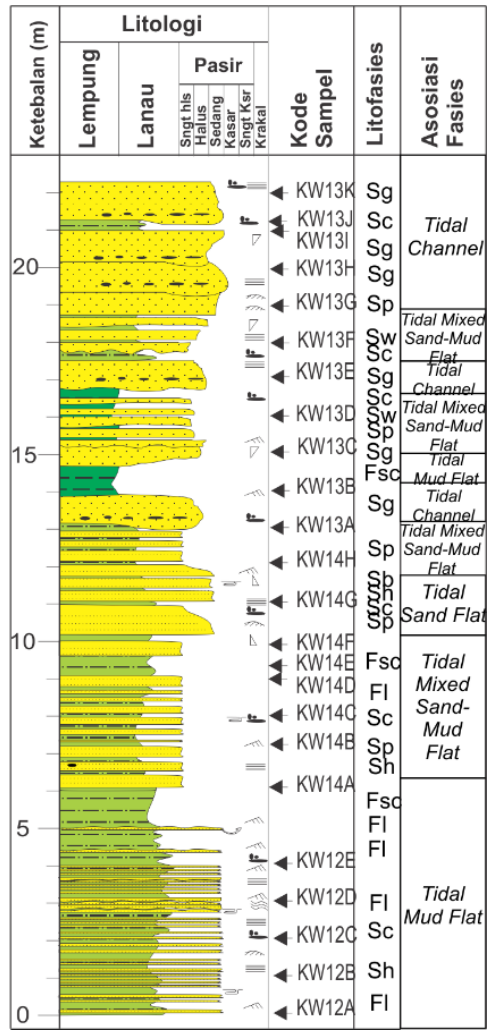

Gambar 14. Profil litologi gabungan yang menggambarkan litofasies dan asosiasi fasies dari setiap lintasan pengamatan: A. Lintasan Lofin; B. Lintasan Oseil; C. Lintasan Niner; D. Lintasan Bula. 


\section{DISKUSI}

Pada penelitian ini ditemukan fosil Halobia (Zittelihalobia) superba (Mojsisovic, 1874). Fosil tersebut penciri umur Carnian Atas hingga Norian Bawah (Trias Akhir) pada salah satu singkapan di Lintasan Bula (Gambar 6.B). Kemp dan Mogg (1992) mengilustrasikan paleogeografi Pulau Seram umur Trias, Pulau Seram (yang sekarang) dulunya merupakan bagian dari batas benua Australian bagian barat laut dan Formasi Kanikeh dapat dikorelasikan dengan satuan-satuan batuan yang terendapkan di batas benua tersebut. Sistem pengendapan yang terjadi pada umur Trias sangat dipengaruhi oleh tektonik subsiden dan intrakratonik lisu (penipisan dalam lempeng benua) (Veevers, 1988). Terjadinya regresi (Bradshaw dkk., 1988) dan tersingkapnya horst batuan dasar (Formasi Kobipoto dan Kompleks Tehoru) oleh proses lisu (penipisan lempeng tektonik) yang terjadi di sepanjang batas benua menjadi sumber material pengendapan Formasi Kanikeh pada cekungan (graben) terdekat. Material hasil erosi tertranspor oleh sistem fluvialdeltaik Trias di bagian tenggara pulau Seram, menyuplai material sedimen yang mengisi lisulisu yang terbentuk saat itu (Kemp dan Mogg, 1992). Secara kronostratigrafi Formasi Kanikeh dapat dikorelasikan dengan Formasi Keskain (Misool - Pigram dkk., 1984), Formasi Dalan (Buru - Pigram dkk., 1982), Formasi Winto (Buton - Davidson, 1991), Grup Aifam/Formasi Tipuma(Irian Jaya), Sahul Grup (lepas pantai laut Bonaparte), Formasi Cape Londonderry (Arufura Barat - McLennan dkk., 1990).

Hasil dari penelitian ini menunjukkan lingkungan pengendapan transisi yang dipengaruhi oleh arus pasang-surut yang termasuk dalam asosiasi fasies tidal channel, tidal sand flat, tidal sand-mud mixed flat, dan tidal mud flat, hal tersebut mendukung hasil penelitian dari O'Sullivan dkk. (1985) yang hasilnya Formasi Kanikeh terendapkan di lingkungan laut dangkal hingga transisi. Pengamatan di lapangan menunjukkan adanya lapisan perulangan batupasir, batulanau, dan batulumpur seperti yang disampaikan oleh Gafoer dkk. (1993), Formasi Kanikeh merupakan sedimen tipe "flysch" atau turbidit terdiri dari perulangan batupasir, batulanau, dan batulumpur. Hasil studi ini menunjukkan perulangan lapisan tersebut bukan endapan turbidit, melainkan endapan pasang-surut yang dicirikan oleh Litofasies Batupasir Karbonan (Sc); Litofasies Batupasir Bergelombang (Sw); Litofasies Batupasir Flaser (Sf); Litofasies Batupasir Laminasi Sejajar (Sh); Litofasies Batulumpur Lentikuler (Fl); Litofasies Batulumpur Berlapis (Fsc). Kemp dan Mogg (1992) juga mendapatkan struktur sedimen yang sama pada lapisan batuan sedimen yaitu stuktur sedimen normal gradasi, silang-siur, konvolut, laminasi bergelombang, struktur lidah api, struktur pembebanan, tikas seruling, dan lapisan flaser-like, serta lapisan batupasir yang kaya akan butiran batubara, namun mereka menggolongkannya sebagai bagian dari sekuen Bouma yang merupakan produk arus gravitasi. Produk arus gravitasi juga dicirikan oleh adanya matrix supported conglomerate. Beberapa sekuen pengendapan oleh arus turbidit juga dicirikan dengan adanya basal konglomerat yang bergradasi menjadi ukuran yang lebih halus dan lapisan yang lebih tipis seperti lapisan batulanaubatulumpur. Tjokrosapoetro dan Budhitrisna (1982) menginterpretasi Formasi Kanikeh terendapkan pada lingkungan neritik hingga endapan flysch pada lingkungan yang cukup dalam pada umur Trias Tengah hingga Jura berdasarkan Aviculadae, Lovcenipora vinassai giatt, Montlivaltia molukkan wanner, dan Halobia sp.

Hasil dari analisis lingkungan pengendapan Formasi Kanikeh pada penelitian ini menunjukkan adanya perbedaan pandangan dengan beberapa peneliti sebelumnya (Audley-Charles dkk., 1979; Tjokrosapoetro dan Budhitrisna, 1982; Kemp dan Mogg, 1992; Gafoer dkk., 1993). Mereka menginterpretasi Formasi Kanikeh terendapkan sebagai sedimen flysch produk arus gravitasi di lingkungan laut dalam dari bukti-bukti dan analisis yang telah dilakukan.

Berdasarkan analisis litofasies dan asosiasi fasies lingkungan pengendapan Formasi Kanikeh dari data yang terdapat di lintasan Lofin, Niner, Oseil, dan Bula mendukung hasil penelitian O'Sullivan dkk. (1985) dan lebih detil pada lingkungan transisi intertidal yang dipengaruhi oleh arus pasang-surut. Hasil analisis ini juga didukung dari hasil analisis palinostratigrafi yang dilakukan oleh Chandra dan Kusworo (2019), yang menunjukkan lingkungan intertidal hingga supratidal. 


\section{KESIMPULAN}

Berdasarkan penelitian yang telah dilakukan dapat disimpulkan Formasi Kanikeh terendapkan dengan sistem pengendapan batuan silisiklastik yang dipengaruhi oleh arus pasang-surut pada lingkungan pengendapan transisi intertidal. Dengan adanya hasil penelitian ini, konsep eksplorasi migas di Cekungan Bula perlu menyesuaikan dengan karakter sekuen pengendapan di lingkungan transisi. Pembagian unit stratigrafi pada Formasi Kanikeh juga perlu ditinjau ulang agar dapat mendapatkan lead dan atau play Mesozoikum baru.

\section{UCAPAN TERIMA KASIH}

Terima kasih kami haturkan kepada Tim Survei Cekungan Bula, Pusat Survei Geologi, Badan Geologi, Kementerian Energi dan Sumberdaya Mineral yang telah memberikan kesempatan untuk melakukan penelitian bersama. Tak lupa kami ucapkan terima kasih atas saran dan masukan yang membangun dari rekan-rekan dosen Teknik Geologi, Universitas Jenderal Soedirman, Purwokerto.

\section{DAFTAR PUSTAKA}

Adlan, R., Wahyudiono, J., Susilo, A., Salimudin, B., Gibran, A.K., Wiratmoko, E.S., 2018. Petroleum system potential of lofin and banggoi area, seram island. Proceedings of Indonesian Petroleum Association. 42. IPA18-250-G

Audley-Charles, M.G., Carter, D.J., Barber, A.J., Norvick, M.S., Tjokrosapoetro, S., 1979. Reinterpretation of the geology of Seram: Implications for the Banda Arc and northern Australia, Journal of the Geological Society of London. 136, 547-568.

Bradshaw, M.T., Yeates, A.N., Beynon, R.M., Brakel, A.T., Langford, R.P., Totterdell, J.M., Yeung, M., 1988. Palaeogeographic Evolution of the North West Shelf Region, in Purcell, P.G. and Purcell, R.R. (Eds.), The North West Shelf of Australia: Petroluem Exploration Society of Australia, North West Shelf Symposium, Perth, Proceedings, pp. 29-54.
Chandra, B.Y., Kusworo, A., 2019. Palynostratigraphy and paleoenvironment of the triassic kanikeh formation, seram island, Indonesia. Proceedings of Indonesian Petroleum Association. 43. IPA19-G-280

Dalrymple, R.W., Knight, R.J., Zaitlin, B.A., Middleton, G.V., 1990. Dynamics and facies model of a macrotidal sandbar complex, Cobequid Bay-Salmon River estuary (Bay of Fundy): Sedimentology. 37,577-612.

Dalrymple, R.W., 1992. Tidal depositional systems, In: Walker, R.G., James, N.P. (Eds), Facies Models: Response to Sea Level Change, Geological Association of Canada, Canada. pp. 195-218.

Davidson, J.W., 1991. The Geology and Prospectivity of Buton Island, Southeast Sulawesi, Indonesia. Proceedings of Indonesian Petroleum Association. 20, 209-234.

Gafoer, S., Suwitodirdjo, K., Suharsono, 1993. Peta Geologi Lembar Bula dan Watubela, Maluku, skala 1:250.000, Pusat Penelitian dan Pengembangan Geologi, Bandung.

Helby, R., Wiggins, V.D., Wilson, G.J., 1987. The circum-Pacific occurrence of the Late Triassic dinoflagellate Sverdrupiella. Australian Journal of Earth Sciences, 34, 151-152.

Hill, K.C., 2012. Tectonic and regional structure of Seram and the Banda Arc, Berita Sedimentologi, Indonesian Journal of Sedimentary Geology. 23, 6-16.

Kemp, G., Mogg, W., 1992. A re-appraisal of the geology, tectonics, and prospectivity of seram island, eastern Indonesia. Proceeding of Indonesian Petroleum Association. 21, 521-552.

Kuecher, G.J., Woodland, B.G., Broadhurst, F.M., 1990. Evidence of deposition from individual tides and of tidal cycles from the Francis Creek Shale (host rock to the Mazon Creek biota), Westphalian D (Pennsylvanian), northeastern Illinois: Sedimentary Geology. 68, 211-221. 
Martini, R. Zaninetti, L. Lathuilliere, B., Cirilli, S., Cornee, J.J., Villeneuve, M., 2004. Upper Triassic carbonate deposits of Seram (Indonesia): palaeogeographic and geodynamic implications. Palaeogeography, Palaeoclimatology, Palaeoecology, 75-102

McLennan, J.M., Rasidi, J.S., Holmes, R.L., Smith, G.C., 1990. The geology and petroleum potential of the western arufura sea. Australian Petroleum Exploration Association Journal. 30(1), 91-106.

Mojsisovics, E., 1874. Über die triadischen pelecypoden-gattungen daonella und halobia, Abhandlungen der k. K. Geologischen Reichsanstalt. 7: 1-35.

O’Sullivan, T.D., Pegum, D., Tarigan, J., 1985. Seram oil search, past discoveries and future oil potential, Proceedings of Indonesian Petroleum Association. 14, 3-20.

Pigram, C.J., Challinor, A.B., Hasibuan, F., Rusmana, E., Hartono, U., 1982. Lithostratigraphy of the Misool Archipelago, Irian Jaya, Indonesia. Geologie en Mijnbouw. 61(3), 265-279.

Pigram, C.J. and Panggabean, H., 1984. Rifting of the Northern Margin of the Australian Continent and the Origins of Some Microcontinents in Eastern Indonesia. Tectonophysics. 107, 331-353.

Reineck, H.E., Wunderlich, F., 1968. Classification and origin of flaser and lenticular bedding: Sedimentology, 11, 99-104.

Shanmugam, G., Poffenberger, M., Álava, J. T., 1998. Tide dominated estuarinne facies in the Hollin and Napo ("T" and "U") formations (Cretaceous), Sacha field, Oriente basin, Ecuador: Extended Abstracts of AAPG Annual Convention. 2, K-Z, A590-A594.

Surjono, S.S., Wijayanti, H.D.K., 2012. Tectonostratigraphic framework of eastern indonesia and its implication to petroleum systems. ASEAN Engineering Journal Part C. 1. 109-123.
Suwitodirdjo, K., Tjokrosapoetro, S., Achdan, A., 1983. Geologi Lembar Masohi, Puslitbang Geologi.

Terwindt, J.H.J., 1981. Origin and sequences of sedimentary structures in inshore mesotidal deposits of the North Sea, in Nio, S.D., Shuttenhelm, R.T.E. dan Van Weering, Tj.C.E. eds., Holocene marine sedimentation in the North Sea Basin: International Association of Sedimentologists, Special Publication. 5, 4-26.

Tjokrosapoetro, S., Budhitrisna, T., 1982. Geology and tectonics of northern banda arc. Bulletin Geological Research and Development Centre, Bandung. 6, 1-17.

Veevers, J.J., 1988. Morphotectonics of Australia's northwestern margin - a review. in Purcell, P.G. and Purcell, R.R. (eds.), The North West Shelf Australia: Petroleum Exploration Society of Australia, North West Shelf Symposium, Perth, Proceedings, 19 - 27.

Wahyudiono, J., Adlan, R., Permanadewi, S., Gibran, A.K. 2018a. Karakteristik Minyak Bumi di Blok Bula dan Blok Oseil, Pulau Seram, Maluku. Jurnal Geologi dan Sumberdaya Mineral. 19, 233-241.

Wahyudiono, J., Susilo, A., Adlan, R., Salimudin, B., Gibran, A.K., Wiratmoko, E.S., 2018b. Integrated field mapping, organic chemistry and subsurface geological interpretation of kanikeh formation as potential source rock in seram island. Proceedings of Indonesian Petroleum Association. 42. IPA18-247$\mathrm{G}$.

Walker, R.G., James, N.P., 1992. Facies Models: Response to Sea Level Change, Geological Association of Canada, Canada. pp. 195-218.. 